\title{
Polyphonic Resonances OF Fairy TAles and MYThS: The MAGIC TOYSHOP AND LIFE BEFORE MAN
}

\begin{abstract}
Angela Carter and Margaret Atwood exploit fairy tale characters, settings, motifs, and plots in their fiction, they are also authors of original reworkings of fairy tales. This article compares the use of fairy-tale elements in Carter's The Magic Toyshop and Atwood's Life Before Man, which not only evoke these resonant forms of story-telling in their titles, character names and plot devices, but create intertexts that parody and give alternate or even reversed meanings to fairy-tale tropes. Both writers see fairy tales as open sources that can be subverted and rewritten. The article focuses on the strategies the authors use to rewrite the traditional patterns of passive female heroine and inscribe a constructive ambiguity.
\end{abstract}

Keywords

Angela Carter; Margaret Atwood; The Magic Toyshop; Life Before Man; fairy tales; intertextuality; fairy tale quest; survival

\section{Fairy tale parodies}

Both Angela Carter and Margaret Atwood draw on fairy tales and re-use elements of recognition, survival, and magical transformation in constructing the identity of their heroines. The use of fairy tales and myths by Atwood and Carter has been discussed by numerous critics, including Danielle M. Roemer and Cristina Bacchilega. Atwood's fairy tale intertextual strategies have been extensively discussed by Sharon Rose Wilson, Brooks Bouson, Shuli Barzilai and others.

Carter and Atwood exploit fairy tale characters, settings, motifs, and plots in their fiction and have also written their own reworkings of traditional fairy tales. 
This article works with the concept that Carter's and Atwood's novels create intertexts with fairy tales, as the writers not only refer to fairy tales in their titles and characters, but, more importantly, reverse, parody, imitate and alter the traditional understanding of fairy tales. Both writers see fairy tales as open sources to be subverted and rewritten.

Carter's fairy tales are stories about fairy tales with a strong emphasis on the use of irony. In "Notes from the Front Line," Carter analyses her strategy of reusing fairy tales:

Reading is just as creative an activity as writing and most intellectual development depends on new readings of old texts. I am all for putting new wine in old bottles, especially if the pressure of the new wine makes the old bottles explode. (1983: 69)

Atwood herself commented on Carter's "role-breaking and role-remaking" (1994: 117) of women in "Running with the Tigers:" "Mercy, pity, peace and love, and especially chastity and motherhood, go out the window; in come ruthlessness, lasciviousness, the separation of sexual pleasure from procreation, and delight in the pain of others" (1994: 119). Margaret Atwood's recycling of fairy-tale motifs is also based on 'role-breaking and role-remaking.'

In Don't Bet on the Prince: Contemporary Feminist Fairy Tales in North America and England, Jack Zipes comments on women writers' versions of fairy tales by observing that they "challenge conventional views of gender, socialisation, and sex roles" (1986: xi). ${ }^{1}$ Carter and Atwood resist the dominant discourse encoded in traditional fairy tales, and they rewrite the plots from different perspectives. By engaging with fairy tales in this way, Carter's and Atwood's novels use fairy tale intertexts to talk back to the oppressors and victimizers.

Recent feminist criticism acknowledges the passivity of Sleeping Beauty and Snow White, however, it also identifies examples of active, strong female characters in fairy tales, for example, Maria Tatar discusses Gretel as a female trickster who represents a more energetic alternative to "comatose heroines like Snow White and Sleeping Beauty." (2015: 39) Carter and Atwood critically challenge the stereotypical passivity of fairy tale heroines. As Atwood comments, "we need not content ourselves with limp compliance or sullen revenge: The creative retelling, the utopian dream, the mischievous reversal, the rightly-chosen wish, and the renewed sense of wonder may instead be ours" (2005: 201) Bucking the trend of concentrating only on fairy tales in which women are "beautiful, dutiful automatons" (2005: 198), Carter and Atwood also present powerful and empowered characters, who challenge fairy tales' function as "brainwashing devices" (2005: 198). While passive female characters such as Cinderella, Snow White, Rapunzel and Sleeping Beauty may be the best known fairy-tale women, the wider body of folklore includes many examples of clever, strong, and cunning female characters. An interesting case is the type of clever trickster who overcomes antagonists and may even come to the rescue of a male character such as a prince or a brother using their intelligence or their grasp of magic. One such character is Little Sister 
in the fairy tale "Little Sister and Little Brother" (ATU 450 in the tale-type index). These brave heroines are reflected in Carter and Atwood's fiction and may have inspired them. Although it is not so obvious in their early fiction, several of their female characters, including Melanie in The Magic Toyshop and Elizabeth in Life Before Man, manifest their own desires, drives for pleasure and decisions to act, to speak out, act out, and to survive. Zsófia Anna Tóth suggests that:

[t]he violence and the 'bad girl' image of femmes fatales are constructed through antagonisms such as power/powerlessness, authority/subjugation, sexual subjects with agency/objects without agency and they are always on the 'winning side' of these antagonisms (2017: 191)

In Carter's and Atwood's novel, these oppositions are subverted and challenged in their heroines' constant criss-crossing and blurring of the boundaries between passivity/activity, powerlessness/power. Melanie (The Magic Toyshop) and Elizabeth (Life Before Man) both navigate through this ambiguity. They want to fight back against paralysis and they exploit the limited levers of control at their disposal, with varied results: Elizabeth, by manipulating others; Melanie by struggling with her own identity and destiny, previewed for her by her mute Aunt Margaret, silenced by Uncle Philip.

Carter and Atwood caricature the conventional concept of the beautiful and dutiful automata and mute dolls as the only positive representation of femininity, they create types of women who challenge the conventions of patriarchal society. Both writers refuse to see fairy-tale characters as objects: they restore women's identities and re-examine their roles and positions in society. It is impossible to analyse all the fairy-tale features in Carter's and Atwood's oeuvre in one article, so I have decided to dedicate this paper to two of their early novels that are less commonly discussed: Carter's The Magic Toyshop and Atwood's Life Before Man. As noted above, fairy-tale elements are strongly present in the other works of both authors and I refer to them where they illustrate my argument.

Fairy tale themes that recur in the work of Carter and Atwood include quests and searches for identity, transformation, healing, and awakening. Perhaps one of the most frequent themes is the quest to survive and narrate. I concentrate on the moments where the selected texts appear to show a hope of success in this quest to survive and transform. In Carter's and Atwood's early novels, transformation can be read as a positive impulse, even though they parody and question the conventional fairy-tale happy endings using an ironic viewpoint. Fascinated by the Bluebeard stories, they develop texts in which the heroine outsmarts the malevolent system (political, class, gender hierarchies). On the other hand, some of them risk becoming Bluebeards themselves (Elizabeth in Life Before Man). In Carter's and Atwood's versions, nobody is completely innocent. Their heroines learn to avoid the traps of happy endings. 


\section{Puppets don't overact: Angela Carter's The Magic Toyshop}

Atwood eulogises Carter as a fairy-tale fairy: "The amazing thing about her, for me, was that someone who looked so much like the Fairy Godmother [...] should actually be so much like the Fairy Godmother" (2005:155). Carter's longer fiction uses strong magic, which is, like most old fairy tales, both aggressive and soothing. The same paradox occurs throughout Carter's fiction where she alludes to motifs and characters from fairy tales. Winged creatures (Nights at the Circus), fairy-god mothers (Heroes and Villains), mysterious pranks, magic transformations (The Magic Toyshop), surprising escapes (Love), and happy endings (The Passion of New Eve; Wise Children) reoccur in her novels.

The Magic Toyshop, is among the richest of Carter's works in fairy-tale elements, including fairy-tale characters, plots, settings and symbols. Chronologically, The Magic Toyshop, written in 1967, is situated between the thematically closer Shadow Dance (1966) and Several Perceptions (1968). The social background creates the stage for Melanie's drama of becoming a woman and thus the novel can be also read as a Bildungsroman. In "Notes on the Gothic Mode," Angela Carter writes that The Magic Toyshop is "a baleful fairytale" (1975: 132).

The plot resembles a typical fairy tale: three orphans, Melanie, her brother Jonathon and sister Victoria, are forced to live with their uncle, who turns out to be a monstrous villain-wizard. His 'enchanted house' is a place where it is difficult to distinguish between reality and fantasy, the authentic self and imitation, life and performance. ${ }^{2}$ Carter creates a Bluebeardian Uncle Philip who manipulates life-size puppets, his family. The link between Perrault's "Bluebeard," (AT 311) and Uncle Philip is created at the beginning: chopped off hands are found in drawers; parts of the dolls (which mean more to Uncle Philip than his own family) recall the mutilated bodies of Bluebeard's wives in a bloody chamber:

The walls were hung with jumping-jacks, dancing bears and leaping Arlecchinos. And also with partially assembled puppets of all sizes, some almost as tall as Melanie herself; blindeyed puppets, some armless, some legless, same naked, some clothed, all with a strange liveliness as they dangled unfinished from their hooks. (MT 67)

Melanie is juxtaposed with these dolls throughout the novel. Within this house of dolls, the real adult woman, Uncle Philip's wife Margaret, is mute (struck dumb on their wedding day), passive and powerless. She is an ironic version of the mute women of fairy tales who are silenced and scared, significantly resembling "The Six Swans" by the brothers Grimm. Thus, Margaret belongs to the long tradition of the sisters who take a vow of silence to rescue their brothers (or themselves). Moreover, while pretending to be entirely compliant, silent, and passive, she carries on a dangerous, incestuous relationship with Finn, her brother, right behind her husband's back.

A swan also features in the novel's climactic horror scene. Uncle Philip forces Melanie to act in a puppet show of the myth "Leda and the Swan". As the per- 
formance begins, Melanie can observe the bird with ironic detachment ("It was nothing like the wild phallic bird of her imaginings. It was dumpy and homely and eccentric" [MT 165]), but soon she finds herself in the position of Leda, an objectified and passive victim. This scene is not only the turning point of the story; it is also one of the most contested in the critical interpretation of the novel.

Carter's fiction has always evoked contrasting critical receptions; many feminist critics who have commented on Bloody Chamber claim that the old fairy tales were a reactionary form that inscribed a misogynistic ideology. ${ }^{3}$ On the other hand, Merja Makinen argues against "critics who cannot see beyond the sexist binary opposition." She calls for a reading that considers the "potential perversity of women's sexuality" (2000: 23 ). This notion is also valid when reading Melanie's 'rape' by the swan. Clearly, writing, like reading/interpreting, inscribes ideologies, but later re-readings need not encode the same postulations. This is why we need not read Melanie's rape and victimization purely as a moment in the acting out of a patriarchal myth but also as a moment in her self-directed exploration of female sexuality and sexual fantasy.

The moment of Melanie's victimisation can be seen as a turning point in her self-awareness and the development of her sexual behaviour. Melanie is obsessed with her image and fashions herself as a Pre-Raphaelite, a Lautrec model with her hair "dragged sluttishly across her face" (MT 1). She wishes to be the object of the gaze ("'Look at me!' she said to the apple tree as it fattened its placid fruit [...]. 'Look at $m e$ !' she cried passionately to the pumpkin moon [...]" [MT 16]). Her newly discovered (sexual) identity is extremely challenged by the changes in circumstances when she is forced to live in the toy-maker's house. Thus, I read the rape-scene as a complicated sexual fantasy in which both Uncle Philip and Melanie are contributing (but not collaborating) authors. "Fantasy" is the word Melanie uses when she imagines the view of the scene: "watching this whole fantasy from another place" (MT 166). The scene thus cannot be read simply as the victimization of a passive girl, but as an ambiguous moment that questions the boundaries between the active subject and the passive object of the sexual fantasy.

Moreover, when Finn is inspired to smash up the swan, Melanie wishes he had not: "Melanie was inside the white igloo of the swan's wings. The swan was too big, too potent, to all at once stop being" (MT 174). Melanie's reply supports my argument that she has ambiguous feelings about the 'rape': she both actively enacted the fantasy and fell victim to it. My point that Melanie's role is more ambiguous than that of her uncle's passive puppet: she attempts to define her feminine identity through her performance, sometimes taking steps to invite and sometimes to reject the male gaze. Melanie's active status is also recognised by Uncle Philip himself when he complains that she was overacting: "You were melodramatic. Puppets don't overact. You spoiled the poetry"' (MT 167).

The motif of rape presents an important link between The Magic Toyshop and Life Before Man. In both novels, the sexual fantasy and "desire to be taken by force," as Tania Modleski observes in Loving with a Vengeance, "conceals 
anxiety about rape and longings for power and revenge" (1982: 48). I argue that Elizabeth in Life Before Man fantasizes rape and violence. She actively seeks out a date with a travelling salesman of fetishist underwear that ends with him sexually assaulting her, but it seems to affect her more as an anti-climax and disappointment than as an act of violence:

"Get your hand off my crotch,"” Elizabeth says. She feels as if she's opened a serious-looking package and a wind-up snake has jumped out. She's never appreciated practical jokes. (LM 141).

In Life Before Man, Atwood dramatizes and challenges not only the sexual dominance of men, but also passive sexuality: Elizabeth is not a woman who gives herself in easy.

Returning to The Magic Toyshop, while Melanie's 'rape' scene functions on one level as a critique of the old inscription of femininity as passive and "the issue of patriarchal control" (Gamble 1997: 72), there is also a note of comedy or laughable absurdity to it. ${ }^{4}$ Moreover, the scene finally breaks Uncle Philip's 'spell' and the characters find the strength to free themselves. Humour and laughter are, in Carter's writing, powerful weapons against tyrannical ideology. When Melanie is frightened of Uncle Philip's life-size puppets, Finn tries to help her to overcome her fear by laughter and ridicule: “'Laugh at me,' he said. 'I'm trying to amuse you" (MT 68). Melanie is overwhelmed and horrified and laughter helps her to overcome it actively.

Melanie's escape with Finn is not a fairy tale happy ending at all. Melanie does not have any happily-ever-after illusion: "She knew they would get married one day and live together all their lives and there would always be pervasive squalor and dirt and mess and shabbiness, always, forever and forever" (MT 177). Carter leaves an open possibility that Melanie is in danger of becoming entrapped in patriarchal marriage, but it is important to recognise Melanie's efforts to escape the trap of objectification, passivity and to return the deadly Bluebeardian gaze. The extent of such liberating feminist perspectives in The Magic Toyshop is still rather tentative, but Carter's early novel explores the possibilities to escape the situation.

Another of the areas that Carter probes and challenges in The Magic Toyshop is mythical narrative. Both she and Atwood tend to use the two terms, fairy tale and myth interchangeably. To support this, I quote Margaret Atwood's interview with Karla Hammond, where she explains myth in this way:

Myths mean stories, and traditional myths mean traditional stories that have been repeated frequently. The term doesn't pertain to Greek myths alone. Grimm's Fairy Tales are just as much myth or story as anything else. But some get repeated so often in the society that they become definitive, i.e. myths of that society. Certainly Biblical ones have been very important in our society. (1990: 114-15)

Whatever theoretical basis there is for separating myths and fairy tales, Jack Zipes suggests that any initial distinctions have vanished in retellings and rewrit- 
ings: "Certainly, myths and folk tales blended very early in the oral tradition" (1994: 5-6). Carter and Atwood cross genre boundaries in their use of myths and fairy tales. They do not rewrite them strictly along the genre conventions. Carter and Atwood challenge and subvert not only fairy tale and mythical archetypes but stereotypes in general. Their criticism of passive heroines is not connected solely to the genre of fairy tale and myth. Carter's and Atwood's reconstructions of fairy tale heroines make them more (psychologically) realistic, human and relatable to the contemporary audience.

Carter creates links between Melanie and the mythical figure of Eve in the Garden of Eden. At the beginning of the novel, Melanie wants to climb a tree in her mother's wedding dress: "Melanie had the courage to slip out of her dress. She pulled her hair around her, to protect herself" (MT 20-21). However, a cat hurts her and the dress is symbolically ripped and stained with her blood. Melanie "was horribly conscious of her own exposed nakedness. She felt a new and final kind of nakedness [...]. A shower of apples fell down around her as she tested the first branch" (MT 21). At this point, Carter juxtaposes Melanie's awareness of her nakedness and the apples, clearly associating Melanie with Eve eating the forbidden fruit. Carter complicates the mythical intertext with references to coldness, darkness and blood. Moreover, there is no Adam in Carter's version. Carter's myth thus seems to expose the complexity of the Biblical myth when a woman's perspective is considered.

In the second edition of Angela Carter, Linden Peach points out that Carter is "challenging a myth which endorses the inferiority of women to men" (2009: 68). The concentration on Melanie's perspective is an important aspect of re-visioning the Biblical myth. Melanie's feelings of pain and fear rewrite Eve's point of view, her punishment and, symbolically, women's life. The end of the novel returns to the myth of Adam and Eve; Melanie and Finn escape the hell-like toyshop, unlike Adam and Eve, who were expelled from the Garden of Eden. Uncle Philip's "Bluebeard's castle" (MT 198) is a stage of emotional, sexual and physical tyranny.

By alluding to fairy tales and myths, The Magic Toyshop questions views that romanticise female suffering and passivity. ${ }^{5}$ Carter's intertextual method, which links The Magic Toyshop to the Bluebeard fairy tale (symbolic parts of female bodies, patriarchal tyrant, mute wife) as well as the myths of "Leda and the Swan" and "Adam and Eve", reminds us of how our actions can be shaped by literary stereotypes. Carter was strongly aware that fairy tales were traditionally used as warning tales to regulate female sexuality. Nevertheless, Carter's ironic detachment and altered perspectives open the possibility of (autonomous) survival outside fairy tales' patterns and conventions.

In an essay on Carter's use of fairy tale motifs, "Angela Carter: Bottle Blonde, Double Drag," Marina Warner discusses Carter's "widespread influence" on the writings of Margaret Atwood (1994: 243). This lies not only in their shared interest in rewriting fairy tales, as has already been mentioned, but also the method of interweaving. However, Carter's adaptation of the fairy tale genre is more overt, 
and changes from her early works to her later writing. Another feature the two authors have in common is the black humour and irony with which they make their texts even more plural and open.

\section{The curse and awakening: Margaret Atwood's Life Before Man}

Atwood reuses fairy tale and mythic motifs, modifies them and, usually, subverts them in order "to reveal contemporary landscapes, characters, and problems" (Wilson 1993: XI). Together with Carter and other women writers, Atwood reconstructs fairy tale images, protagonists and motifs, which, paradoxically, have often been used as boundaries to restrict women's lives and roles but at the same time offer a scaffolding for identity construction and transformation. Atwood's female (and male) protagonists survive by transforming themselves through magical healing (The Edible Woman), a refusal of the "poisonous apple" which represents large amounts of food (Lady Oracle) or sexual abuse (The Blind Assassin), ritual isolation (Surfacing), and magical amputation of (un)wanted parts (bodily parts or memories) of themselves (Lady Oracle, Life Before Man, Cat's Eye, Alias Grace). I suggest that Atwood's characters follow (or refuse to follow) fairy tale patterns to survive and heal themselves. Some of them break out of the role of an innocent and obedient girl and become powerful manipulators and vindicators (Zenia in The Robber Bride, Elizabeth in Life Before Man). Thus, they challenge the stereotypes of fairy tale characters, enriching the interpretative possibilities of fairy tales.

Fairy tales form a referential text but they are also used to provide a self-reflexive framework for the "double-voiced discourse" of dialogism (Bakhtin 1981: 327). Atwood's echoes of fairy tales or myths constitute more than simple inspiration or reference. Her strategy of creating fairy tale intertexts is paradoxical, parodic and deconstructive, rather than a simple following of the patterns. Her texts are open and usually resist closure, she rejects hackneyed fairy-tale happy endings. Atwood writes beyond the reader's expectations and beyond the genre or conventional use.

Atwood's use of the fairy tale genre has been widely discussed by numerous critics, but one of her early novels, Life Before Man (1979) has received much less attention than any other of her novels. This is the reason why I deal with the analysis of fairy tale elements in Life Before Man in particular. I focus on the fairy tale subtexts that are also present in Carter's The Magic Toyshop: "The Sleeping Beauty" and "Bluebeard," or, more importantly, the Grimms' "The Robber Bridegroom" (AT 955) or "The Fitcher's Bird" (AT 311). Another link between the novels is a rape fantasy and the character of a toymaker (Uncle Philip in The Magic Toyshop and Nate in Life Before Man). In inserting fairy-tale intertexts, Atwood uses specific strategies. She constructs her plots using fairy-tale imagery, such as very noticeable mirror, glass, and black and white imagery of the "Snow White" in Life Before Man: "In the oak-framed oval mirror above the dressing 
table she can see the door opening, the darkness of the hall behind, Nate's face bobbing like a pale balloon." (LM 5), but she goes against this fairy tale, because here, Elizabeth is both, a Snow White behind "the soundless glass panel of the hospital nursery" (LM 4) as well as a manipulative Evil Queen and/or Bluebeard, leaving headless lovers behind. Atwood also reverses and doubles the fairy-tale plots and genders of characters in an unpredictable manner, for example, she recreates the Bluebeardian character in form of a Bluebeardian couple of Elizabeth and Nate who go through their lovers, leaving them helpless (at best, like Martha), or headless and mutilated like Chris (who commits suicide after Elizabeth leaves him). By reversing the traditional plots, she shows how the norms or ideology of the intertexts can be transgressed, not necessarily leading to happy endings.

Life Before Man depicts the complicated love triangles of Elizabeth and Nate Schoenhof and their lovers: Nate's lover Lesje Green and her partner William and Elizabeth's former lover Chris. Without Atwood's typical relieving humour and obsessive references to fairy tales, the characters would live very stereotypical and boring lives. The novel's central location is the Royal Ontario Museum, where Elizabeth and Lesje work. The imagery of ice age and fossilization reinforces the atmosphere of passivity, enchantment, entrapment, and sleep. The characters seem to be incapable of genuine human love and passion. The connection between Life Before Man and "The Sleeping Beauty" and "Snow White" is established at the beginning, when Elizabeth lies in her bed and she is clothed, mourning over the suicide of Chris:

somewhere between her body, which is lying sedately on the bed, on top of the Indian print spread, tigers and flowers, wearing a black turtleneck pullover, a straight black skirt, a mauve slip, a beige brassiere with a front closing, and a pair of pantyhose, the kind that come in plastic eggs, and the ceiling with its hairline cracks. (LM 4)

At the beginning of the novel, she seems to be passive and unable to act, although she refuses to allow herself to appear helpless. Atwood's version of "Sleeping Beauty" and "Snow White" is written against the fairy tale plot, by depicting a claustrophobic and brutal world in which awakening does not provide any kind of hope.

The passivity of the three protagonists is surpassed by Elizabeth's mother and Caroline, her sister. Elizabeth's mother "had finally succeeded in frying herself to a crisp in that last tiny room on Shuter Street, setting fire to her mattress with a dropped cigarette and too drunk to know she was burning" (LM 106). Caroline drowned herself in a bathtub. Since Caroline lies on a blanket, "arms folded across her breasts, eyes open and fixed on the ceiling" (LM 164), she is totally immobile within her "sealed body" ( $L M 77)$, which, in my opinion, creates a link between her and "Snow White," the fairy tale character most criticized by "narrowly focused" feminist critics for her passivity (Wilson 1993: 13) ${ }^{6}$ The Snow White imagery, associated with Elizabeth, runs through the text: "She stops in front of a newspaper box, bending to look in through the square glass window 
[...] she needs something in black and white" $(L M 50)$ Elizabeth is framed by the window in a direct reference to the beginning of the fairy tale. Although Sharon Rose Wilson suggests that characters in Life Before Man wait and hope "for someone to give them salvation" (2008: 15), their inactivity is much more complex. Elizabeth is far from the stereotype of a passive girl waiting to be loved or admired. She is portrayed as a skilful manipulator, facing her (erotic) rivals, listening to them directly, without a magic mirror. Here, again, Atwood rewrites the fairy-tale power politics by presenting Elizabeth as both a passive woman helplessly lying on her bed and an active, manipulating witch queen. I argue that this is another link between The Magic Toyshop and Life Before Man, because Melanie and Elizabeth are both characters who cannot be fixed to one pole of an active-passive dichotomy, which is one of the structures classically imposed on fairy tales. As has been already pointed out, Melanie is not a mere puppet in the hands of her Uncle, and similarly, Elizabeth is fighting for power, even if she is temporarily powerless and paralyzed by the suicide of her ex-lover. It is not only social power that Elizabeth fights for as a career focused woman, she also fights in her domestic sphere, with her husband as well as her auntie Muriel:

Elizabeth stamps her bare feet, exultant. Revolution! Auntie Muriel is as good as dead; she will never have to see her again. She does a small victorious dance around her pressback pine chair, hugging herself. She feels savage, she could eat a heart. (LM 201)

As Cathy and Arnold Davidson suggest, Elizabeth is introduced in a "passive, helpless role," but she is "not just a survivor," she is also a "fighter" and "a most capable victimizer" with "almost indomitable strength" (1981: 217). Such a powerful image is strengthened by a metaphor of cannibalistically eating one's enemy's heart. As I have already suggested, Elizabeth takes up the role of a Bluebeard. Unlike other fairy tale orphans, clever and resourceful girls who save their siblings ("Little Brother and Little Sister," "Hansel and Gretel", "Six Swans"), she is unable to save her paralyzed sister Caroline. Elizabeth transforms herself from a motherless orphan, from her "hunger and unbrushed hair" ( $L M 144)$ to a powerful Bluebeardian manipulator: "She let him see he was deficient and she promised, what? A transformation, a touch on the shoulder, knighthood. Then she'd stepped back, showing him that he was after all only a vacation, a beautiful picture on a brochure, a man in a loincloth whacking the head off some nondescript coconut $[\ldots]$ treated him the way men treat women." (LM 145) By going against the fairy tale expectations, she displaces the truth of traditional narratives and also sheds light on traditional characters, showing them much less passive as we thought they were. For example, by reversing the gender of fairy tale protagonists, she enables us to see their hidden power. In Life Before Man, Nate is associated with the image of Cinderella, always working around the house, seemingly pleasing everybody, cooking, cleaning, preparing cups of tea, always dirty, covered in sawdust: "Get your ashes hauled" (LM 24) Like Cinderella, he is leaving his house in secret, to be with his lover, Lesje. However, he is not as harmless as he pretends to be. 
Lesje, isolated in her empty house, evokes the image of Rapunzel, impregnated by a Prince. Unlike the fairy tale character, Lesje does not go blind for having a lover, she is woken up by her pregnancy. Lesje, fascinated by those who used to work at the museum, realizes that she "belongs here" (LM 283). The job of a palaeontologist gives her power to "go through those doors: secrets, wonders even, lay beyond. Now she has keys, she can go almost anywhere." (LM 283) Another Bluebeardian or "Fitcher Bird" reference to keys and secret doors shows that Atwood's heroines draw on the model of resourceful and clever girls in Grimms' fairy tales. Lesje's pregnancy transforms her in a positive way; she wants to make her decision by herself, not dependant on what her mentor thinks, or how Nate would feel: "[...] her final decision will not be based on it. Nate has been displaced, if only slightly, from the center of the universe." (LM 284) Unlike the fairy tale Rapunzel, she gets to choose her own path.

Yet, there is a difference between the two novels. In The Magic Toyshop, it is mostly Melanie who is depicted as a multi-dimensional character; the other characters, including Uncle Philip, who is portrayed as a caricature or a cartoon of himself, are presented mostly within fairy tale conventions. But in Life Before Man, most of the protagonists are both victims of their power struggles and accomplices in sexual violence. While Elizabeth refuses to be a victim, Nate, (paradoxically) thinks of himself as a passive victim "a lump of putty, helplessly molded by the relentless demands and flinty disapprovals of the women he can't help being involved with" ( $L M 33$ ), yet, as is typical of Atwood, the victim is very often themselves causing harm to someone else. Bouson suggests that Nate "is depicted as the Atwoodian innocuous male" but he also "envisions himself as a wolflike predator" (1993: 101). During the divorce phase with Elizabeth, he feels "a swift desire to stand up and lean over her, put his hands around her neck and squeeze. There would be some satisfaction in that" (LM 238). In my reading, this points to his frustration with passivity and lack of control in his life and a (mistaken) sense that the only way to take control is aggression.

The moment of fairy tale awakening, which is linked to sexual awakening and maturity in Carter's book, also marks the moment of Melanie's rebellious liberation from Uncle Philip's toyshop. In Atwood's novel, awakening is more complicated: Elizabeth contemplates her past, thinking about her mother and her Auntie Muriel. Reminiscing about her unhappy childhood, she labels her mother as Glinda the Good and Auntie Muriel as the Wicked Witch from "The Wizard of Oz." Only when Auntie Muriel talks about her mother in the hospital, is Elizabeth able realize that her mother never was the "wronged party, a saint under the street lights" (LM 259) as she had always believed her to be. Auntie Muriel, whom she always saw as an evil stepmother, is revealed to be the only person who took care of her mother. Atwood rewrites the fairy tale imagery of good and evil in a more nuanced way.

Unlike the ending of Carter's novel, there is no Prince to awaken the Beauty in Atwood's Life Before Man. The characters need to recollect their own past to be able to act (to wake up) in the future. Only acknowledging their childhood 
traumas (the fairy-tale curse) can help them to survive. As has been shown, Atwood writes against the fairy-tale plot. In their passivity (sleep) the characters realize the curse and thus, wake up from a long sleep, back to reality: "Elizabeth dabs at her nose. If she wants to see grapes she can go the supermarket. She has to go there anyway, since there's nothing in the house for dinner" (LM 291). Paradoxically, hunger pangs activate her to get up and overcome her paralysis.

Contrary to Atwood's previous three novels (The Edible Woman, Lady Oracle and Surfacing), the author chooses not to conclude her novel with an open ending. The characters, after a long period of sleep, make decisions, wake up and act on. However, it is not a fairy tale happy ending promising a happy marriage and/ or restoration of a traditional family. ${ }^{7}$

\section{Conclusion: Happily ever after (?)}

Melanie and Elizabeth end up stepping forward. They are not passive dolls any more, still, their active control over their lives is not articulated. The protagonists of Carter's and Atwood's early novels are unable to verbally express their hidden emotions of anger, hatred, and desire and they use bodily gestures of hysteria or mutism to escape or resist the dominance of men. For conventional Gothic and fairy tale heroines, escapes (and weddings), literal or metaphorical, usually mean rescue, but they might present only tragic, immature and temporary solutions for Melanie (The Magic Toyshop), Annabel (Love), Surfacer (Surfacing), Elizabeth (Life Before Man) and Joan (Lady Oracle). Moreover, the traditional patterns and plots serve as paradigms for new dilemmas followed by open-ended and ironic resolutions of traditional happy endings. In Carter's and Atwood's rewritings, the protagonists "wake up" to begin living their own lives. In their early novels, along fragile beauties, they present much stronger and active resourceful and clever girls: Anne Bossom (Several Perceptions) and Marian (Edible Woman), cured from their hysteria, realize they are free to refuse the role of mother and wife. Other characters, Emily (Shadow Dance), Marianne, Surfacer, Elizabeth and Lesje, take responsibility for their pregnancy and parenthood. Melanie matures and (possibly) moves beyond her trauma. Although still unable to talk back to the puppet master, the protagonists have some hope of completing the transformation from puppets to active and decisive women.

\section{Notes}

Thomas Bonnici suggests that "[i]n the rather mysterious world of orature the contents of the European fairy-tale have been a constant vehicle for the transmission of patriarchal ideology and feminine submission" (1998: 9). He continues that the genre of fairy tales is synonymous with the passivity of women (1998: 10). Recent feminist criticism acknowledges the passivity of some princess-like characters in fairy tale, however, it also identifies examples of active, strong and clever heroines in fairy tales. 
2 Donna Mitchell discusses the novel as an example of Gothic narrative in which the heroine is "demoted to the status of a silent and submissive doll-like entity" (2017: 4). The development of the story copies Melanie's psycho-sexual development and we see that it is much more dynamic and complex.

3 In this line, Patricia Duncker accuses the genre of fairy tales of being "the carrier of ideology" and claims that Carter "amplifies and re-produces rather than alters the original, deeply, rigidly sexist psychology of the erotic" (1984: 6). Mitchell says that in The Magic Toyshop, Melanie appears to be "demoted to the status of a silent and submissive doll-like entity" (2017: 4), while Gruss calls her "a collaborator in this patriarchal myth" (2009: 140).

4 In this line, Gina Wisker argues that "the near rape of girl by man-controlled, man-constructed beast of power is plain, real, monstrous" and continues that "while the full reality of the horror of this enacted power relationship is emphasized, it is also debunked, satirized, laughed at" (1994: 111).

$5 \quad$ In "Feminism and Fairy Tales", Rowe argues that "[f]airy tales perpetuate the patriarchal status quo by making female subordination seem a romantic desirable, indeed an inescapable fate" (1986: 237).

6 Sarah Appleton discusses Atwood's use of fairy tale wicked women in her novels. She suggests that "second-wave feminist images of women have ended up emphasizing a new set of stereotypes by depicting women as victims of men. To Atwood, this development has been distressing." (2013: 278) Atwood's reconstruction of fairy tale characters shows them much more complex and far from innocent.

7 Sherrill Grace thinks that the ending lacks transformations: "history repeats itself" (1980: 138). Still, most critics read the ending as providing "hope that life before man is not merely a bleak matter of the survival of isolated individuals" (Beran 1990: 70-71). Most of the characters find their strength and power to live their lives, not only survive.

\section{References:}

Appleton, Sarah (2013) Freed from the salt mines of virtue: Wicked women in Margaret Atwood's novels. In: Bouson, J. Brooks (ed.) Critical Insights: Margaret Atwood. Ipswich: Salem Press, 276-294.

Atwood, Margaret (1990) Articulating the mute. Interview by Karla Hammond. In: Ingersoll, Earl

G. (ed.) Margaret Atwood: Conversations . Princeton: Ontario Review Press, 191-220.

Atwood, Margaret (1980) Life Before Man. Toronto: Seal.

Atwood, Margaret (1994) Running with tigers. In: Sage, Lorna (ed.) Flesh and the Mirror: Essays on the Art of Angela Carter. London: Virago Press, 117-135.

Atwood, Margaret (2005) Angela Carter: 1940-1992. In Curious Pursuits: Occasional Writing, Margaret Atwood. London: Virago Press, 155-159.

Atwood, Margaret (2005) Not so grimm: The staying power of fairy tales. In: Atwood, Margaret. Curious Pursuits: Occasional Writing. London: Virago Press, 197-203.

Bakhtin, Mikhal Mikhailovich (1981) The Dialogic Imagination: Four Essays. Trans. Michael Holquist. Austin: University of Texas.

Beran, Carol (1991) The Canadian mosaic: Functional ethnicity in Margaret Atwood's Life Before Man. Essays in Canadian Writing 41 (Summer 1990): 59-73.

Bonnici, Thomas (1998) Angela Carter's critique of phallocentrism in 'The Bloody Chamber and Other Stories'. Acta Scientarum 20(1): 9-15. Accessed on November 11, 2017.

Bouson, J. Brooks (1993) Brutal Choreographies: Oppositional Strategies and Narrative Design in the Novels of Margaret Atwood. Amherst: University of Massachussetts Press.

Carter, Angela (1967) The Magic Toyshop. London: Penguin.

Carter, Angela (1975) Notes on the gothic mode. The Iowa Journal, 6(3/4): 132-134. Accessed on April 4, 2011. 
Carter, Angela (1983) Notes from the front line. In: Wandor, Michelene (ed.) On Gender and Writing. London: Pandora, 69-87.

Davidson, Arnold E. and Cathy N. Davidson (1981) Prospects and retrospects in Life Before Man. In: Davidson, Arnold and Cathy Davidson (eds.) The Art of Margaret Atwood: Essays in Criticism. Toronto: Anansi, 205-223.

Duncker, Patricia (1984) Re-imagining the fairy tales: Angela Carter's bloody chambers. Literature and History 10(11): 3-14. Accessed on February 5, 2011.

Gamble, Sarah (1997) Angela Carter: Writing from the Front Line. Edinburgh: Edinburgh University Press.

Grace, Sherill (1980) Violent Duality: A Study of Margaret Atwood. Montreal: Véhicule Press.

Gruss, Susanne (2009) The Pleasure of the Feminist Text: Reading Michéle Roberts and Angela Carter. Amsterdam: Rodopi.

Makinen, Merja (2000) Angela Carter's 'The Bloody Chamber'and the Decolonisation of Feminine Sexuality. In: Easton, Alison (ed.) Angela Carter. Houndsmills: Macmillan, 20-36.

Mitchell, D., (2017) Leda or living doll? Women as dolls in Angela Carter's The Magic Toyshop. Studies in Gothic Fiction 5(2): 4-12. Accessed on April 30, 2018.

Modleski, Tania (1982) Loving with a Vengeance: Mass-Produced Fantasies for Women. London: Routledge.

Peach, Linden (2009) Angela Carter. $2^{\text {nd }}$ ed. Houndsmills: Palgrave Macmillan.

Rowe, Karen E. (1986) Feminism and fairy tales. In: Zipes, Jack (ed.) Don't Bet on the Prince: Contemporary Feminist Fairy Tales in North America and England. New York: Methuen, 209-226.

Tatar, Maria (2015) Female tricksters as double agents. In: Tatar, Maria (ed.) The Cambridge Companion to Fairy Tales. Cambridge: Cambridge University Press, 39-60.

Tóth, Zsófia Anna (2017) Disney's violent women: in quest of a 'fully real' violent woman in American cinema. Brno Studies in English 43(1): 185-212.

Warner, Marina (1994) Angela Carter: Bottle blonde, double drag. In: Sage, Lorna (ed.) Flesh and the Mirror: Essays on the Art of Angela Carter. London: Virago Press, 243-256.

Wilson, Sharon Rose (1993) Margaret Atwood's Fairy-Tale Sexual Politics. Jackson: University Press of Mississippi and ECW Press.

Wilson, Sharon Rose (2008) Myths and Fairy Tales in Contemporary Women's Fiction: From Atwood to Morrison. New York: Palgrave Macmillan.

Wisker, Gina (1994) Weaving our own web: Demythologising/Remythologising and magic in the work of contemporary women writers. In: Wisker, Gina (ed.) It's My Party: Reading Twentieth Century Women's Writing. London: Pluto Press, 104-128.

Zipes, Jack (1994) Fairy Tale as Myth: Myth as Fairy Tale. Lexington: University of Kentucky Press.

Zipes, Jack, ed. (1986) Don't Bet on the Prince: Contemporary Feminist Fairy Tales in North America and England. New York: Methuen.

Katarína Labudoví teaches British and Canadian postmodern literatures at the Department of English Language and Literature, Faculty of Arts and Letters, Catholic University in Ruzomberok, Slovakia. She gained her Ph.D (2011) in the field of Comparative Literatures at the University of Masaryk, Brno, Czech Republic. Her dissertation deals with Angela Carter's and Margaret Atwood's strategies of writing beyond genre conventions. Katarina Labudova has published several articles focused on identity, monstrosity and the representations of the body. Apart from this, her research interests include Slovak and Romani fairy tales and the role of female tricksters in them.

Address: Katarina Labudova, Ph.D., Department of English Language and Literature, Faculty of Arts and Letters, Catholic University in Ružomberok, Hrabovská cesta 1, 03401 Ružomberok, Slovakia. [email: katarina.labudova@ku.sk] 